\title{
Do Athletes Claim Handicaps in Low Ego-Threatening Conditions? Re-Examining the Effect of Ego-Threat on Claimed Self-Handicapping
}

\author{
Lucie Finez and Sophie Berjot \\ University of Reims Champagne Ardennes \\ Elisabeth Rosnet \\ INSEP, French National Institute of Sport \\ Christena Cleveland \\ Westmont College
}

\begin{abstract}
One hundred and three athletes participated in a motor task that was ostensibly designed to detect their physical ability (high ego-threatening condition) or provide pretesting data for an upcoming study (low ego-threatening condition) and were then given the opportunity to claim handicaps that could impair their performance on this task. Extending previous findings that high self-handicappers (i.e., athletes who scored high on the self-handicapping scale) and low self-esteem athletes engage in claimed self-handicapping in high ego-threatening conditions, the results reveal that they may also engage in this strategy in low ego-threatening conditions. In the low ego-threatening condition, athletes' self-esteem and self-handicapping tendency explained together $33 \%$ of the handicaps they claimed.
\end{abstract}

Self-handicapping is a proactive strategy that individuals use to obtain a protective excuse for failure and/or to enhance credit for success during a performance situation. This strategy consists of adopting or claiming impediments to success before performing. Most researchers distinguish acquired and claimed self-handicapping (e.g., Hirt, Deppe, \& Gordon, 1991). Acquired (or behavioral) self-handicapping refers to actively creating impediments to one's performance (e.g., missing training sessions) and claimed self-handicapping refers to verbally claiming that disruptions may interfere with performance (e.g., reporting a pain). Athletes who engage in selfhandicapping may, for instance miss training sessions (behavioral self-handicapping) or report physical pain before a competition (claimed self-handicapping) so that, if they underperform, their failure may be attributed to these handicaps (lack of training

Finez and Berjot are with the Laboratory of Applied Psychology, University of Reims Champagne Ardennes, Reims, France. Rosnet is with INSEP, French National Institute of Sport, Paris, France. Cleveland is with the Dept. of Psychology, Westmont College, Santa Barbara, CA. 

or physical pain) rather than to their lack of abilities. Conversely, if they succeed despite these handicaps their success may be more linked to their physical abilities. During the last five years, claimed self-handicapping has received a large amount of interest, particularly in the field of sports (e.g., Elliot, Cury, Fryer, \& Huguet, 2006; Greenlees, Jones, Holder, \& Thelwell, 2006; Kuczka \& Treasure, 2005). Indeed, this strategy is used quite frequently in sports (for a review see Prapavessis, Grove, \& Eklund, 2004) and can negatively affect athletes' social relationships, self-image and performance (see e.g., Elliot et al., 2006; Martin, 1996). It would be useful for coaches, sport psychologists and sport teachers to use techniques to prevent self-handicapping (Kuczka \& Treasure, 2005). To accomplish this, one would need to accurately predict which athletes are most likely to engage in claimed self-handicapping and when they are most likely to do so.

To reach this goal, we need to explore both the personal characteristics of individuals that are more likely to engage in claimed self-handicapping (personal determinants) and the situations in which this strategy may appear (situational determinants).While several dispositional determinants of claimed self-handicapping namely, self-handicapping tendency and self-esteem-have been identified (e.g., Carron, Prapavessis, \& Grove, 1994; Greenlees et al., 2006; Prapavessis \& Grove, 1998), the situational determinants of claimed self-handicapping, have received less empirical examination. Studies that invested the situational determinants of this strategy mostly focused on variables linked to the climate of a group (e.g., motivation and cohesion, Carron et al., 1994; Kuczka \& Treasure, 2005) and less on the nature of the task itself or more specifically on the threat generated by a task. In addition, the situational and dispositional determinants of claimed self-handicapping have almost never been studied simultaneously, that is to say by considering the interaction of situational and dispositional factors on self-handicapping (interactionist point of view, Kimble \& Hirt, 2005). Consequently, two major questions remain.

First, it remains unclear whether athletes use claimed self-handicapping in low ego-threatening conditions. The literature clearly indicates that athletes engage in this strategy in high ego-threatening situations such as competitions or physical tests (e.g., Ferrand, Champely, \& Brunel, 2005; Kuczka \& Treasure, 2005). However, to our knowledge, no research addresses whether athletes also use this strategy during low ego-threatening situations (e.g., conditioning training exercises or techniques training exercises without any salient evaluative components $)^{1}$. Second, while it is evident that high self-handicappers and low self-esteem athletes can engage in claimed self-handicapping (Carron et al., 1994; Coudevylle, Martin Ginis, \& Famose, 2008; Greenlees et al., 2006), whether low self-handicappers and high self-esteem athletes also engage in this strategy remains unclear. The present work uses the interactionist approach to investigate the effect of self-handicapping tendency and self-esteem level on the emergence of claimed self-handicapping in two conditions (high and low ego-threatening situations).

\section{Claimed Self-Handicapping in Low Ego-Threatening Situations}

Given that self-handicapping was initially defined as a strategy used "to shape the implications of performance feedback" to protect (or enhance) one's competence image (Jones \& Berglas, 1978, p. 202), this strategy has generally been studied in evaluative situations. In most experiments on claimed self-handicapping participants were placed in high ego-threatening situations; athletes completed competitions or 
physical tests (Carron et al., 1994; Ferrand et al., 2005; Greenlees et al., 2006) and students completed exams or intelligence tests (Feick \& Rhodewalt, 1997; Hirt et al., 1991; Strube, 1986). These studies have shown that claimed self-handicapping strategies are particularly likely to emerge during high ego-threatening situations. However, up to this point, no study has investigated whether claimed self-handicapping strategies are also likely to emerge during low ego-threatening situations. Nevertheless, general research can shed light on this topic.

On the one hand, we can reference research outside of the field of sports in which ego-threat was manipulated (high vs. low), and claimed self-handicapping subsequently measured (DeGree \& Snyder, 1985; Smith, Snyder, \& Perkins, 1983). In these studies, the high and low ego-threatening conditions were respectively operationalized by an intelligence test and a nonevaluative cognitive task that would generate pretesting data for an upcoming study. In both of these experiments, participants engaged more in claimed self-handicapping in the high ego-threatening condition than in the low ego-threatening condition.

On the other hand, still outside of the field of sports, we can reference research in which ego-threat (high $v s$. low) and difficulty of the task (high vs. low) were manipulated (Rhodewalt \& Fairfield, 1991, studies 1 and 2). High self-handicappers who anticipated a difficult test reported lower intention of effort (more self-handicapping) than low self-handicappers both in the high and low ego-threatening conditions. These findings only partially support the authors' predictions that selfhandicapping would only emerge in the difficult, high ego-threatening condition. Rather, they suggest that high self-handicappers may engage in behavioral selfhandicapping even in low ego-threatening situations. Further, in an other study that was designed to investigate the consequences of self-handicapping on performance, Deppe and Harackiewicz (1996) observed that high self-handicappers engaged in more behavioral self-handicapping compared with low self-handicappers before participating in a pinball game both in a competitive condition (that included a high evaluative component) and in a noncompetitive condition (that lacked an evaluative component).

Although the experiments of Rhodewalt and Fairfield (1991) and Deppe and Harackiewicz (1996) were not designed to test the emergence of self-handicapping in low ego-threatening conditions, they suggest that high self-handicappers may engage in this strategy even when they are faced with low evaluative situations - and which should be, by nature, low ego-threatening. Surprisingly, these findings were not highlighted and have received little attention in the literature even though they are inconsistent with the initial (Jones \& Berglas, 1978) and most defended position (see e.g., Self, 1990) that self-handicapping emerges to shape the implication of performance feedback.

On the basis of these results, we hypothesize that self-handicapping strategies can emerge in situations with and without performance feedback. More specifically, while applying this hypothesis to the emergence of claimed self-handicapping in the field of sport, we proposed that some athletes, and particularly those who present a high self-handicapping tendency, may engage in claimed self-handicapping strategies not only in high ego-threatening situations such as competitions or physical tests but also in low ego-threatening situations.

In the same manner, other athletes, and particularly those with low self-esteem, may also engage in claimed self-handicapping in low ego-threatening situations. 
Low self-esteem individuals are indeed known to engage in strategies to protect their self (for a review see Baumeister, Tice, \& Hutton, 1989). In this sense, two studies suggest that in comparison with high self-esteem athletes, low self-esteem athletes engage in more self-handicapping before participating in a physical test (Coudevylle et al., 2008; Martin \& Brawley, 2002). It is possible that low selfesteem athletes differ from high self-esteem athletes not only by their tendency to engage more in claimed self-handicapping in high ego-threatening situations, but also by their tendency to engage in this strategy in a wider range of situations.

\section{Claimed Self-Handicapping Among Low Self-Handicappers and High Self-Esteem Athletes}

Several studies indicate that high self-handicappers claim more handicaps than low self-handicappers (Carron et al., 1994; Finez, 2008; Greenlees et al., 2006); while low self-esteem athletes claim more handicaps than high self-esteem athletes (Coudevylle et al., 2008; Martin \& Brawley, 2002) when they are faced with high ego-threatening events like a competition or a physical test. But the data from these studies, do not address whether low self-handicappers and high self-esteem athletes do or do not engage in claimed self-handicapping because there was only one condition (a high ego-threatening condition). Two studies focusing on self-handicapping in its behavioral form suggest that high self-esteem individuals engage in behavioral self-handicapping and that they do so to enhance their image of competence (Newman \& Wadas, 1997; Tice, 1991). To our knowledge, no study has investigated whether high self-esteem individuals engage in claimed self-handicapping or whether low self-handicappers engage in this strategy.

The present study attempted to address two main issues. First, we tested whether high self-handicappers and low self-esteem athletes engage in claimed self-handicapping in low ego-threatening sports situations. Secondly, we observed whether low self-handicappers and high self-esteem athletes engage in claimed self-handicapping strategies when they are faced with high ego-threatening sports situations.

\section{Method}

\section{Overview}

The design was a 2 (Self-handicapping tendency: High $v s$. Low) $\times 2$ (Self-esteem: High vs. Low $) \times 2$ (Ego-threatening situation: High $v s$. Low) factorial design. The study was conducted in two phases. In phase 1, participants were asked to complete a questionnaire packet including self-handicapping and self-esteem scales. Consistent with previous researchers, we constituted the groups of low and high self-handicappers by selecting participants in the bottom and top thirds of the score distribution (respectively, CSHS-S scores $<24$ and $>32$; see e.g., Rhodewalt \& Fairfield, 1991; Thompson \& Richardson, 2001). Participants with scores in the middle third of the score distribution were not invited to participate in second phase of the experiment. This selection criterion enabled researchers to detect an effect of self-handicapping tendency on self-handicapping. However, due to the fact that self-handicapping tendency and self-esteem level were not correlated, 
using the same selection criterion to create the groups of high and low self-esteem participants would imply to exclude many participants ${ }^{2}$. As such, to avoid losing too many participants, and because it is not necessary to exclude the participants with scores in the middle third of the score distribution on the self-esteem dimension to observe an effect of self-esteem on self-handicapping (see e.g., Strube \& Roemmele, 1985; Tice, 1991; Tice \& Baumeister, 1990), the groups of low and high self-esteem athletes were distinguished a posteriori on the basis of median splits (scores below and above 24 for physical self-esteem, and score below and above 37 for global self-esteem).

The aim of phase 2 was to manipulate ego-threat and to assess athletes' engagement in claimed self-handicapping. Three weeks after phase 1, in an ostensibly unrelated setting, selected participants were contacted to participate in a physiological experiment ostensibly conducted by the physiological laboratory of their university. Participants were randomly assigned to the high $(n=51)$ and low $(n$ $=52$ ) ego-threatening conditions while controlling the sex-ratio. Approval of the study protocol was obtained from the ethics committee of the university.

\section{Participants}

Volunteer students of the Kinesiology University of Amiens (France) who practice sport competition at a level ranging from regional to international were recruited to participate in this study. In total 195 athletes participated in phase 1 , from which 103 participated in phase 2 . They were 73 males and 30 females $(M$ age $=19.5$; $S D=1.5)$ from a variety $(n=30)$ of team and individual sports. They trained an average of $7.1 \mathrm{hr}$ per week.

\section{Material and Procedure}

Phase 1 During regular university courses, participants completed a questionnaire presented to them as part of a study on athletes' strategies.

Self-Handicapping Tendency. The self-handicapping tendency was assessed with the Claimed Self-Handicapping Scale in Sport (CSHS-S, Finez, 2008). This scale is composed of eight items associated with a seven-point Likert scale ranging from 1 (strongly disagree) to 7 (strongly agree). Four items assess the self-handicapping tendency for self-protective motives (e.g., "When I feel bad physically (lack of sleep, pain, etc.), I tell the others before starting the competition so that if I fail, the others will think that I have failed, in part, because of this obstacle"). Four items assess the self-handicapping tendency for self-enhancing motives (e.g., "When I'm not prepared enough for a competition, I tell the others before starting the competition, so that if I succeed despite of this obstacle, the others will think that I'm more competent). The CSHS-S has been found to have satisfying validity and reliability for athletes (Finez, 2008, studies 1, 2 and 4). This scale has demonstrated high internal consistency (Cronbach's alphas range from .86 to .88 in three different studies) and the examination of its construct validity indicated that its score correlates positively with constructs that are theoretically linked to self-handicapping such as ego goal orientation $(r=.31)$, entity theory of ability $(r=.26)$, public self-consciousness $(r=.33)$, social perfectionism $(r=.42)$ 
or self-esteem instability $(r=.25)$. In addition, it has demonstrated high test-retest reliability (Pearson's $r=.82$ ) at a four weeks interval. Further, the confirmatory factor analysis confirmed the existence of the two factors: Self-protection and self-enhancing motives (GFI $=.98 ; \mathrm{CFI}=1.00$; RMSEA <.001). Finally, the CSHS-S has demonstrated its ability to predict athletes' engagement in claimed self-handicapping both in natural and experimental settings.

The CSHS-S was used rather than the Self-Handicapping Scale (SHS, Jones $\&$ Rhodewalt, 1982) which is generally used to assess self-handicapping tendency (e.g., Deppe \& Harackiewicz, 1996; Rhodewalt \& Fairfield, 1991; Thompson \& Richardson, 2001) because it specifically measures claimed self-handicapping. Further, unlike the CSHS-S, the SHS assesses both self-protective and selfenhancing motives of self-handicapping, which is essential to measure all aspects of self-handicapping, not simply its self-protective motives (Tice, 1991). Finally, this scale was especially developed for the population of athletes, which is necessary to study self-handicapping in the field of sports (Martin \& Brawley, 1999).

Self-Esteem. Self-esteem level was assessed with the French version (Berjot, Gregg, \& Richards, 2004) of Fleming and Courtney's (1984) adaptation of the Feelings of Inadequacy Scale. The Self-Regard and Physical Abilities subscales were used to assess respectively global and physical self-esteem ${ }^{3}$. Responses to all questions were made on a seven-point Likert scale ranging from 1 (strongly disagree) to 7 (strongly agree).

Perceived Importance of Physical Abilities. Previous research suggest that the perceived importance of an event plays an important role in ego-threat (e.g., Schultheiss \& Brunstein, 2000). Individuals may only feel threatened by a task if it assesses central components of their self (Self, 1990). As such, athletes may feel threatened by a physical ability test only if the possession of high physical abilities is central for them. Participants were asked to indicate on a Likert scale ranging from 1 (strongly disagree) to 7 (strongly agree) their agreement with four statements such as: "It is important for me to have . . . 1- high physical abilities; 2high qualities of force; 3 - high qualities of speed; 4- high qualities of coordination" $(\alpha=.59)$. Participants who reported placing little importance on the possession of high physical abilities (score under the midpoint of the Likert scale; $n=6$ ) were dropped from the study before phase 2 because they may not have felt threatened by the motor task.

Phase 2 Selected athletes were contacted to participate in a physiological experiment; the purpose of the experiment was not specified. To avoid strategic absences in phase 2, participants were not informed of the bogus purpose of the physiological experiment before arriving at the laboratory. The anonymous code they had reported on the questionnaire of phase 1 was used to locate and contact them.

Upon each participant's arrival, a female experimenter (the first author of this study) — who was unaware of participants' scores on the self-esteem and selfhandicapping scales - informed them that they would individually complete four successive tasks and that she would supervise only the motor task (task 4).

Manipulation of Ego-Threat (Task 1). The first task was used to manipulate ego-threat. All participants were asked to read a notice describing the focus of 
the (alleged) experimental study, and then watched a video presentation of the motor task they would complete. Instructions in the video tape were presented by an actor pretending to be a coach of the National Olympic Committee. The video was used to increase the credibility and stability of instructions. During the video, participants were also presented with illustrations of the motor task that they would complete (the same illustrations were presented to participants in all conditions). The manipulation of ego-threat was adapted from one used in previous studies (see e.g., DeGree \& Snyder, 1985; Rhodewalt \& Fairfield, 1991; Smith et al., 1983) to fit with the population of athletes.

Participants in the high ego-threatening condition were told that they would participate in a study designed to test the relationship between physical abilities and athletics performance and that they would participate in a test on a force plate to measure their physical abilities. A force plate is an instrument used to measure the ground reaction forces generated by a body standing on or moving across it. They were informed that the results of their tests would be used by a computer program to calculate their level of physical ability and that the experimenter would send them their results within 10 days. To increase the credibility of these instructions, participants were asked to indicate their sex, date of birth, sport and best performances during the last two seasons on a questionnaire which was supposed to be used by the experimenter to report their future results on the test. They were told the following:

To ensure a reliable measure of your physical abilities, we use a physical ability test designed by the National Olympic Committee for the preparation of the London 2012 Olympic Games. This test was specially developed to evaluate the physical abilities that are essential to high performance in Olympics sports. Its ability to accurately predict the future performances in individual and collective sports have been proven [... ].

In contrast, participants in the low ego-threatening condition were told that they would participate in a pilot study and that they would execute a motor task on a force plate to calibrate it, and thus help to prepare the device for an upcoming study. They were told:

You will take part in a task aimed only at calibrating the material. [ . . ] your performance on this task will not enable us to evaluate your physical abilities. You will not receive any feedback on your performance. However, we ask that you put forth your best effort on this task.

Unlike participants in the high ego-threatening condition, participants in the low ego-threatening condition were not asked to record their identity, demographic information or performance history.

Measure of Claimed Self-Handicapping (Task 2). The second task was aimed at assessing athlete's engagement in claimed self-handicapping. Participants first read instructions about the effect of momentary physical and psychological state on task performance. These instructions were adapted from those used by Smith, Snyder and Handelsman (1982). Participants of the high ego-threatening condition read the following: 
The results of this test could be affected by the participants' state of mind at the moment of the test. Athletes who are tired, ill, anxious or who encounter any other problem, usually get results significantly below their true level of ability. Therefore we would like you to fill out a questionnaire about your current state.

In the low ego-threatening condition the same instructions were proposed, preceded by: "So as to reliably calibrate the material, we would like you to fill out a questionnaire assessing your present state of mind."

Then, participants rated the extent to which potential handicaps were likely to interfere with their execution on the task. They responded to the statement "My result to the test might be disrupted by ..." associated with a list of 15 potential handicaps and a seven-point Likert scale ranging from 1 (strongly disagree) to 7 (strongly agree). The list of potential handicaps was adapted from Kuczka and Treasure (2005) and included handicaps such as "injury," "anxiety," or "academic worries." Similarly to the procedure used by Kuczka and Treasure (2005), participants could report additional handicaps. Only the participants of the high ego-threatening condition were invited to report their name on this questionnaire. Claimed self-handicapping was assessed by calculating the mean of disruption reported such that higher scores indicated more self-handicapping (see Kuczka \& Treasure, 2005; Smith et al., 1982).

Manipulation Checks (Task 3). To test whether participants had carefully read the instructions about the effect of state of mind on performance, participants were asked: "Do you think that a negative physical or psychological state could decrease your performance on the test?" This question was associated with a five-point Likert scale ranging from 1 (strongly disagree) to 5 (strongly agree).

Motor Task and Debriefing (Task 4). Finally, participants took part in a motor task which consisted of performing a series of coordinated movements and jumps shown by a computer program on a fake force plate. The experimenter debriefed participants collectively when they had all completed phase 2 of the experiment (about one week after).

\section{Results}

\section{Analytical Strategy}

Data were analyzed with multiple regressions to test the main effects and interactions between the independent variables (self-handicapping tendency, self-esteem and condition) on the amount of handicaps reported. Before conducting the regression analyses, the dichotomized independent variable (ego-threatening condition) was transformed into contrast codes (low ego-threatening, -1; high ego-threatening, 1) and the continuous independent variables (self-handicapping tendency and selfesteem level) were centered. Furthermore, to better satisfy the conditions of the application of the linear model and the normality of residuals (Mosteller \& Tukey, 1977), the dependent variable (mean of disruption reported) was logarithmically transformed (i.e., $\log 10)$.

Because the results were quite similar while using the measures of physical and global self-esteem, only the results obtained with the physical self-esteem are 
presented here. The results obtained with the global self-esteem are summarized in footnotes (see footnote $n^{\circ} 4$ ).

With regard to sex differences, women reported lower physical self-esteem compared with men $(t(101)=6,14, p<.01)$. However, no sex effect was observed on claimed self-handicapping, thus the data from males and females were analyzed together.

Manipulation Checks and Control Measures. Participants reported that a low physical or psychological state could decrease their performance on the test (mean above the midpoint of the five-point scale; $M=3.78 ; S D=1.13$ ). They also reported placing high importance on the possession of high physical abilities $(M=5.70 ; S D$ $=.89$ ). Cronbach's alpha of the three items used to assess this measure was rather low $(\alpha=.59)$. This could be explained by the fact that participants were recruited from a wide range of sports, each requiring very different physical qualities. Thus, depending on his/her sport, an individual may place varying levels of importance on possessing force, speed and/or coordination abilities.

Descriptive Statistics and Preliminary Analysis. Claimed self-handicapping (assessed by the mean of disruption reported by participants) ranged from 1 to $5.60(M=2.77 ; S D=.97)$. The means of claimed self-handicapping tendency, physical self-esteem and global self-esteem were respectively $26.28(S D=11.13$, range from 8 to $56 ; \alpha=.91) ; 24.48(S D=5.53$, range from 5 to $35 ; \alpha=.75)$ and $35.83(S D=6.55$, range from 7 to $49 ; \alpha=.71)$. The scores of global and physical self-esteem were significantly correlated $(r=.47 ; p<.05)$.

Preliminary analysis indicated that the scores of self-handicapping tendency and self-esteem level were not significantly correlated $(r=.10$ for global self-esteem; $p>.05$ and $r=-.09$ for physical self-esteem; $p>.05)$ and that the groups of high and low self-handicappers did not differ in their level of self-esteem; $t(99)=.26$, $n s$, for physical self-esteem and $t(99)=1.40, n s$ for global self-esteem. Preliminary analysis also revealed that the means of self-handicapping tendency, physical selfesteem and global self-esteem of participants in the low and the high ego-threatening conditions were not significantly different which suggests that the distribution of participants in each condition was successfully randomized; respectively $t(101)=$ $.68 ; p>.05 ; t(99)=.17 ; p>.05$ and $t(99)=.47 ; p>.05$.

Claimed Handicaps as a Function of Self-Handicapping Tendency, Physical Self-Esteem and Condition. All the effects (main and simple interaction) were significantly related to the mean of disruption reported by participants, $F(5,95)=$ $16.63 ; R^{2}$ adjusted $=.44 ; p<.01$. The condition $(B=.52)$, the self-handicapping tendency $(B=.19)$, their interaction $(B=-.20)$, the physical self-esteem $(B=-.21)$ and its interaction with the condition $(B=.20)$ significantly affected claimed handicaps (see Table 1). The three-way interaction (condition $\times$ self-handicapping tendency $\times$ physical self-esteem) that was not significant was removed from the model ${ }^{4}$.

In the low ego-threatening condition, high self-handicappers claimed more disruptions than low self-handicappers (respectively, $M=2.60$ and $M=2.00$; see Table 2) and low physical self-esteem participants claimed more disruptions than high physical self-esteem participants (respectively, $M=2.61$ and $M=1.94$; see Table 2). These results suggest that high self-handicappers and low physical selfesteem athletes do use claimed self-handicapping when they are faced with a low ego-threatening situation. 


\section{Table 1 Effect of Self-Handicapping Tendency, Physical Self- Esteem and Condition, on the Mean of Disruption Reported by Participants}

\begin{tabular}{lccccc}
\hline Variables & $\mathbf{B}$ & $\begin{array}{c}\text { Std. } \\
\text { Error }\end{array}$ & \multicolumn{1}{c}{$\mathbf{t}$} & $\mathbf{p}$ \\
\hline Intercept & .41 & .01 & & 34.20 & $<.001$ \\
Condition & .08 & .01 & .52 & 6.90 & $<.001$ \\
SH Tendency $(\mathrm{SH})$ & $<.01$ & $<.01$ & .19 & 2.48 & .015 \\
Condition $\times$ SH & $<.01$ & $<.01$ & -.20 & -2.60 & .011 \\
Physical Self-Esteem (PSE) & -.01 & $<.01$ & -.21 & -2.71 & .008 \\
Condition $\times$ PSE & .01 & $<.01$ & .20 & 2.66 & .009 \\
\hline
\end{tabular}

Note: Condition $\times \mathrm{SH}=$ interaction between condition and self-handicapping tendency; Condition $\times$ $\mathrm{PSE}=$ interaction between condition and physical self-esteem.

\section{Table 2 Means of Disruption Reported by Low and High Self- Handicappers, and Low and High Self-Esteem Athletes in Each Experimental Condition}

\begin{tabular}{lcc}
\hline & \multicolumn{2}{c}{ Conditions } \\
\cline { 2 - 3 } & $\begin{array}{c}\text { Low } \\
\text { Ego-Threatening }\end{array}$ & $\begin{array}{c}\text { High } \\
\text { Ego-Threatening }\end{array}$ \\
\hline Low Self-Handicappers & $2.00(.72)$ & $3.16(.64)$ \\
High Self-Handicappers & $2.60(.99)$ & $3.21(.71)$ \\
Low Physical Self-Esteem Athletes & $2.61(.83)$ & $3.19(.67)$ \\
High Physical Self-Esteem Athletes & $1.94(.90)$ & $3.15(.68)$ \\
\hline
\end{tabular}

Note. $n=24,26$ or 27 per cell. Numbers represent the means of disruption reported by participants. Numbers in parentheses represent the standard deviation of the mean of disruption reported.

In addition, both low self-handicappers and high self-esteem athletes claimed more handicaps in the high ego-threatening condition than in the low ego-threatening condition (respectively, $\mathrm{M}=3.16$ and $\mathrm{M}=2.00$ for the low self-handicappers) and (respectively, $M=3.15$ and $M=1.94$ for the high self-esteem athletes). These results suggest that low self-handicappers and high self-esteem athletes do use claimed self-handicapping when they are confronted with a high ego-threatening situation.

Interestingly, the results also reveal that together, self-handicapping tendency, physical self-esteem and condition, better predict claimed handicaps $\left(R^{2}\right.$ adjusted $=$ $.44)$ than self-handicapping tendency and condition alone $\left(R^{2}\right.$ adjusted $\left.=.36\right)$. This increase of explained variance of the amount of disruption reported after the addition of physical self-esteem in the predictors was statistically significant, $F(2,95)=$ $8.11 ; p<.01$. In other words, self-handicapping tendency and physical self-esteem complement each other to predict athletes' claimed handicaps. 


\section{Discussion}

The first objective of the present work was to determine whether athletes engage in claimed self-handicapping when they are faced with low ego-threatening situations. Our results revealed that, in the low ego-threatening condition, high selfhandicappers claimed more handicaps than low self-handicappers, and low selfesteem athletes claimed more handicaps than high self-esteem athletes. These data suggest that athletes with high self-handicapping tendency and/or low self-esteem do use claimed self-handicapping in some low ego-threatening situations ${ }^{5}$. Before discussing these results, it is worth noting that, consistent with previous claimed self-handicapping studies, the methodology we used does not prevent athletes from engaging in sandbagging strategies in addition to self-handicapping strategies. Sandbagging is a false claim or feigned demonstration of inability used to lower observers' expectations for one's performance (see Gibson \& Daniel, 2000). Thus, in the current study, athletes may have claimed handicaps, not only to have an anticipative excuse (claimed self-handicapping), but also to decrease observers' expectations regarding their performances (sandbagging).

The position defended and observed in the current study expands on the notion that self-handicapping strategies emerge to shape the implications of performance feedback (Jones \& Berglas, 1978; Self, 1990). We propose that self-handicapping strategies can emerge in situations with and without expected performance feedback. Indeed, in the current study some athletes engaged in claimed self-handicapping in the low ego-threatening condition, a condition without an evaluative component and in which they were clearly informed that they would not receive feedback.

Our results are consistent with the findings of previous research in which high self-handicappers students engaged in self-handicapping in a situations with low evaluative components (Rhodewalt \& Fairfield, 1991, studies 1 and 2) or in a noncompetitive task (Deppe \& Harackiewicz, 1996). Our findings, however, differ from these studies on three points. First, our results concern not only high self-handicappers but also low self-esteem participants. Second, our results focus on claimed self-handicapping. Third, we examined a different kind of population: Athletes. Further, the previous studies were not specifically designed to test the emergence of self-handicapping in low ego-threatening situations but rather to investigate the consequences of this strategy. Thus, the emergence of behavioral self-handicapping in low ego-threatening conditions was not hypothesized nor formally tested.

It is also necessary to point out that, consistent with previous work (DeGree \& Snyder, 1985; Smith et al., 1983; Snyder, Smith, Augelli, \& Ingram, 1985) our results suggest that claimed self-handicapping is more prevalent in high egothreatening situations than in low ego-threatening situations. Indeed, we observed a positive effect of ego-threat on the amount of handicaps reported by participants: high self-handicappers and low self-esteem athletes claimed more handicaps in the high than in the low ego-threatening condition. Despite the fact that claimed self-handicapping is more prevalent in high ego-threatening situations, its potential emergence in low ego-threatening situations should not be neglected. This is particularly noteworthy because athletes are routinely faced with low ego-threatening situations such as technical or tactical exercises during training. In addition, it was in the low ego-threatening condition that claimed self-handicapping was better 
predicted by self-handicapping tendency and self-esteem level. Indeed, while in the low ego-threatening condition, high self-handicappers claimed more handicaps than low self-handicappers, and low self-esteem athletes claimed more handicaps than high self-esteem athletes; in the high ego-threatening condition this difference disappeared. This finding is consistent with several studies in which the effects of self-handicapping tendency (Rhodewalt, Saltzman, \& Wittmer, 1984) and selfesteem (Ferrand et al., 2005) on the amount of handicaps reported by participants in a high ego-threatening situation was not significant. This finding is also consistent with the position of Kimble and Hirt (2005) that there are many situations in which a situational factor overrides individual differences in self-handicapping tendency and that it is necessary to use an interactionist approach to understand the conditions of emergence of self-handicapping strategies.

Further investigation should focus on determining why high self-handicappers and low self-esteem athletes engage in claimed self-handicapping in low egothreatening situations. One hypothesis is that they feel threatened by any motor task, even those without any salient evaluative component. We can indeed assume that high self-handicappers and low self-esteem athletes perceive threats in most sport situations because they believe that any situation could inform them (or others) on their physical abilities. When self-handicappers and low self-esteem individuals care a great deal about a domain, they could try to evaluate themselves, thus making any situations related to this domain high evaluative and high ego-threatening. It is also possible that, for high self-handicappers and low self-esteem athletes, simply anticipating a failure leads to feelings of threat, regardless of whether the situation is related to central components of the self. Rhodewalt and Fairfield (1991) relied on this explanation when discussing why some students behaviorally self-handicapped in their low ego-threatening condition. This explanation could also be applied to low self-esteem athletes since low self-esteem individuals are particularly concerned about failure (for a review see Baumeister et al., 1989).

Another hypothesis that deserves further investigation is that these athletes did not feel threatened by the low ego-threatening condition but reported handicaps because they had incorporated these handicaps. Indeed, Higgins and Snyder (1988; p. 249) hypothesized that individuals who are regularly confronted with evaluative situations construct an always-available excuse ("incorporated excuse") they use in all situations. They explained that, unlike the anticipatory excuse which is strategically invoked before a probable bad performance, "the incorporated excuse is simply "there" and available for most failure experiences." We can imagine that high self-handicappers and/or low self-esteem athletes put forward handicaps whenever they are faced with motor tasks, even if they do not perceive them as threatening, because they have incorporated excuses.

To test these two main hypotheses (perception of threat in the low ego-threatening condition versus incorporated excuses) it would be necessary to investigate the threat that is experienced by participants who engage in claimed self-handicapping. This task is difficult and has not yet been attempted. New implicit measures such as the patterns of cardiovascular responses proposed by Blascovich and his colleagues (e.g., Blascovich \& Mendes, 2000; Blascovich, Seery, Mugridge, Norris, \& Weisbuch, 2004) would provide a means of accomplishing this task. Their biopsychosocial model describes a method that used patterns of cardiovascular responses to accurately and implicitly estimate the threat that individuals experience. 
The second objective of the current study was to test whether low self-handicappers and high self-esteem athletes do engage in claimed self-handicapping. Our results revealed that they did so in the high ego-threatening condition. To our knowledge, no study has provided evidence that low self-handicappers or high self-esteem individuals do engage in claimed self-handicapping. These findings are however consistent with those of Tice (1991) or Newman and Wadas (1997) who observed that high self-esteem individuals engaged in behavioral self-handicapping (the other expression of self-handicapping) to enhance their image of intellectual ability. We believe that, in the same manner, high self-esteem athletes claim handicaps to enhance their image of physical abilities.

The present study suggests applications for coaches, sport psychologists or sport teachers. First, it reveals that claimed self-handicapping tendency and the self-esteem level accurately predict claimed self-handicapping emergence among athletes. The prediction is even more accurate when using these two variables together than when using either variable alone. Previous research has reached similar conclusions for claimed (Finez, 2008) or behavioral (Richards, Johnson, Collins, \& Wood, 2002) self-handicapping. As Finez (2008) proposed, self-esteem level may enable researchers and practitioners to estimate athletes' motivation to protect and/or enhance their self, while claimed self-handicapping tendency may enable researchers and practitioners to estimate the extent to which athletes are likely to engage in claimed self-handicapping to do so. In the present experiment, self-esteem and self-handicapping tendency appeared particularly pertinent to predict claimed self-handicapping in the low ego-threatening condition, where they explained together $33 \%$ of the amount of handicaps reported by athletes (or $30 \%$ with the measure of global self-esteem $)^{6}$. Note that our groups of high and low self-handicappers were created by excluding participants whose scores were in the middle third of the distribution, thus the prediction might have been slightly lower if we had used a median split to create groups.

Further, our results suggest that coaches who plan to implement interventions to reduce claimed self-handicapping should consider all their athletes rather than focusing only on athletes identified as having a high propensity to engage in claimed self-handicapping and/or a low level of self-esteem. All athletes are susceptible to engage in this strategy, particularly when they participate in high ego-threatening tasks such as competitions or physical tests. In addition, coaches should be aware that some athletes, notably those with a high propensity to engage in claimed self-handicapping and/or those with a low self-esteem level, are susceptible to use this strategy in any kind of sport situation even those that lack a salient evaluative component, such as technical, tactical or physical conditioning training exercises. We also believe that these findings can be generalized to a population of students. Findings from the academic field are indeed generally consistent with those observed in the sport field (see e.g., Prapavessis et al., 2004). Then, it seems likely that high and low self-handicappers as well as high and low self-esteem students do engage in claimed self-handicapping before their exams; and that high self-handicappers and low self-esteem students engage in this strategy, not only before their exams but also in non evaluative circumstances.

To prevent self-handicapping, coaches, psychologists and teachers can use different techniques (see e.g., Kuczka \& Treasure, 2005; Siegel, Scillitoe, \& Parks-Yancy, 2005). For example, they can change the motivational climate of their 
group, focus athletes' attention away from the implication of performance, promote athletes' self-esteem or alter the specific responses athletes use to protect their self. However, these techniques are probably not suitable for all individuals in all situations and should be applied specifically to particular individuals in particular contexts. Thus, it is necessary to consider both the dispositional and situational determinants of claimed self-handicapping and apply techniques accordingly.

\section{Notes}

1. Theoretically, low ego-threatening situations (also called low ego-relevance, or non evaluative settings) refers to situations that do not assess central components of the self; whereas high ego-threatening situations refers to situations that assess relevant components of the self and that have an uncertain issue (e.g., DeGree \& Snyder, 1985; Rhodewalt \& Fairfield, 1991). Then, competitions or physical tests which inform athletes on their physical abilities are generally considered as highly threatening for their self (e.g., Martin \& Brawley, 2002), while sports situations without any salient evaluative components can be considered as minimally threatening.

2. If one excludes the participants who are in the middle third of the score distribution on the self-handicapping dimension, and excludes the participants who are in the middle third of the score distribution on the self-esteem dimension, one could potentially exclude approximately half of the participants of the study. Further, we preferred to exclude participants whose self-handicapping score was in the middle third of the distribution before phase 2 as opposed to after phase 2 . We did this with the goal of reducing the number of participants that took part in phase 2 .

3. In previous work, both, the FIS and the Rosenberg Self-esteem Scale (SES, 1965) have been used to predict self-handicapping (e.g., Newman \& Wadas, 1997; Prapavessis \& Grove, 1998). We opted for the FIS because it is multidimensional, and it enabled us to assess both global and domain-specific self-esteem, such as physical self-esteem.

4. Quite similarly, the regression conducted while using the measure of global self-esteem reveals a significant effect of the condition $(B=.54)$, the self-handicapping tendency $(B=.25)$, the interaction between the condition and the self-handicapping tendency $(B=-.24)$, the global self-esteem $(B=-.26)$ and a marginal effect of the interaction between the condition and the global self-esteem $(B=.13 ; p=.09) ; F(5,95)=16.13 ; R^{2}$ adjusted $=.43 ; p<.01$. The three-way interaction (condition $\mathrm{x}$ self-handicapping tendency $\mathrm{x}$ global self-esteem) was not significant.

5. Note that the similarity observed here between the results of high self-handicappers and the results of low self-esteem athletes cannot be due to the fact that high self-handicappers participants have a particularly low self-esteem level because the scores of self-handicapping and self-esteem were not correlated. The absence of correlation observed between the scores of the CSHS-S and the level of self-esteem is consistent with previous findings (Finez, 2008, studies 1 and 4) and coherent given that both low and high self-esteem individuals may engage in self-handicapping (see e.g., Newman \& Wadas, 1997; Tice, 1991).

6. Supplementary analyses led separately by conditions reveal a positive effect of selfhandicapping tendency and a negative effect of self-esteem in the low ego-threatening condition; $F(2,48)=13.01 ; R^{2}$ adjusted $=.33 ; p<.001$ while using the measure of physical self-esteem; and $F(2,48)=11.94 ; R^{2}$ adjusted $=.30 ; p<.001$ while using the measure of global self-esteem.

\section{Reference}

Baumeister, R. F., Tice, D., M., \& Hutton, D. (1989). Self-presentational motivations and personality differences in self-esteem. Journal of Personality, 57(3), 547-579. 
Berjot, S., Gregg, A., \& Richards, L. (2004, September). Validation française de la version révisée de l'échelle de "Sentiment d'Inadéquation" ("Feeling of Inadequacy Scale") Fleming \& Courtney, 1984. Paper presented at the 5ème Colloque International de Psychologie Sociale en Langue Française de l'ADRIPS, Lausanne, Switzerland.

Blascovich, J., \& Mendes, W.B. (2000). Challenge and threat appraisals: The role of affective cues. In J.P. Forgas (Ed.), Feeling and thinking: The role of affect in social cognition (pp. 59-82). Paris: Cambridge University Press.

Blascovich, J., Seery, M.D., Mugridge, C.A., Norris, R.K., \& Weisbuch, M. (2004). Predicting athletic performance from cardiovascular indexes of challenge and threat. Journal of Experimental Social Psychology, 40(5), 683-688.

Carron, A.V., Prapavessis, H., \& Grove, R.J. (1994). Group effects and self-handicapping. Journal of Sport \& Exercise Psychology, 16(3), 246-257.

Coudevylle, G., Martin Ginis, K.A., \& Famose, J-P. (2008). Determinants of self-handicapping strategies in sport and their effects on athletic performance. Social Behavior and Personality, 36(3), 391-398.

DeGree, C.E., \& Snyder, C.R. (1985). Adler's psychology (of use) today: Personal history of traumatic life events as a self-handicapping strategy. Journal of Personality and Social Psychology, 48(6), 1512-1519.

Deppe, R.K., \& Harackiewicz, J.M. (1996). Self-Handicapping and intrinsic motivation: Buffering intrinsic motivation from the threat of failure. Journal of Personality and Social Psychology, 70(4), 868-876.

Elliot, A.J., Cury, F., Fryer, J.W., \& Huguet, P. (2006). Achievement goals, self-handicapping, and performance attainment: A mediational analysis. Journal of Sport \& Exercise Psychology, 28(3), 344-361.

Feick, D.L., \& Rhodewalt, F. (1997). The double-edged sword of self-handicapping: Discounting, augmentation, and the protection and enhancement of self-esteem. Motivation and Emotion, 21(2), 147-163.

Ferrand, C., Champely, S., \& Brunel, P.C. (2005). Relations between female students' personality traits and reported handicaps to rhythmic gymnastics performance. Psychological Reports, 96(2), 361-373.

Finez, L. (2008). Comprendre et prédire les stratégies d'auto-handicap revendiqué dans le domaine du sport: une approche interactionniste. Unpublished doctoral dissertation, Université de Reims Champagne-Ardenne, France.

Fleming, J.S., \& Courtney, B.E. (1984). The dimensionality of self-esteem: II. Hierarchical facet model for revised measurement scales. Journal of Personality and Social Psychology, 46(2), 404-421.

Gibson, B., \& Daniel, S. (2000). Sandbagging as a self-presentational strategy: Claiming to be less than you are. Personality and Social Psychology Bulletin, 26(1), 56-70.

Greenlees, I.A., Jones, S., Holder, T., \& Thelwell, R.C. (2006). The effects of self-handicapping on attributions and perceived judo competence. Journal of Sports Sciences, 24(3), 273-280.

Hirt, E.R., Deppe, R.K., \& Gordon, L.J. (1991). Self-reported versus behavioral selfhandicapping: Empirical evidence for a theoretical distinction. Journal of Personality and Social Psychology, 61(6), 981-991.

Jones, E.E., \& Berglas, S. (1978). Control of attributions about the self through self-handicapping strategies: The appeal of alcohol and the role of underachievement. Personality and Social Psychology Bulletin, 4(2), 200-206.

Jones, E.E., \& Rhodewalt, F. (1982). The Self-Handicapping Scale. Salt Lake City, UT: Available from Frederick Rhodewalt, Department of Psychology, University of Utah.

Kimble, C.E., \& Hirt, E.R. (2005). Self-focus, gender, and habitual self-handicapping: Do they make a difference in behavioral self-handicapping? Social Behavior and Personality, 33(1), 43-56. 
Kuczka, K.K., \& Treasure, D.C. (2005). Self-handicapping in competitive sport: Influence of the motivational climate, self-efficacy, and perceived importance. Psychology of Sport and Exercise, 6(5), 539-550.

Martin, K.A. (1996). Self-handicapping in sport and physical activity: An elusive concept. Unpublished doctoral dissertation, University of Waterloo, Canada.

Martin, K.A., \& Brawley, L.R. (1999). Is the Self-Handicapping Scale reliable in non-academic achievement domains? Personality and Individual Differences, 27(5), 901-911.

Martin, K.A., \& Brawley, L.R. (2002). Self-handicapping in physical achievement settings: The contributions of self-esteem and self-efficacy. Self and Identity, 1(4), 337-351.

Mosteller, F. W., \& Tukey, J., W. (1977). Data analysis and regressions: A second course in statistics. MA: Addison-Wesley.

Newman, L.S., \& Wadas, R.F. (1997). When stakes are higher: Self-esteem instability and self-handicapping. Journal of Social Behavior and Personality, 12(1), 217-232.

Prapavessis, H., \& Grove, J.R. (1998). Self-handicapping and self-esteem. Journal of Applied Sport Psychology, 10(2), 175-184.

Prapavessis, H., Grove, J.R., \& Eklund, R.C. (2004). Self-presentational issues in competition and sport. Journal of Applied Sport Psychology, 16(1), 19-40.

Rhodewalt, F., \& Fairfield, M. (1991). Claimed self-handicaps and the self-handicappers: The relation of reduction in intended effort to performance. Journal of Research in Personality, 25(4), 402-417.

Rhodewalt, F., Saltzman, A.T., \& Wittmer, J. (1984). Self-handicapping among competitive athletes: The role of practice in self-esteem protection. Basic and Applied Social Psychology, 5(3), 197-209.

Richards, H.D.B., Johnson, G., Collins, D.J., \& Wood, J.E. (2002). Predictive ability of self-handicapping and self-esteem in physical activity achievement context. Personality and Individual Differences, 32(4), 589-602.

Rosenberg, M. (1965). Society and the adolescent self-image. Princeton, NJ: Princeton University Press.

Schultheiss, O.C., \& Brunstein, J.C. (2000). Choice of difficult tasks as a strategy of compensating for identity-relevant failure. Journal of Research in Personality, 34(2), 269-277.

Self, E.A. (1990). Situational influences on self-handicapping. In R.L. Higgins, C.R. Snyder, \& S. Berglas (Eds.), Self-handicapping: The paradox that isn't (pp. 37-68). New York: Plenum Press.

Siegel, P.A., Scillitoe, J., \& Parks-Yancy, R. (2005). Reducing the tendency to self-handicap: The effect of self-affirmation. Journal of Experimental Social Psychology, 41(6), 589-597.

Smith, T.W., Snyder, C.R., \& Handelsman, M.M. (1982). On the self-serving function of an academic wooden leg: Test anxiety as a self-handicapping strategy. Journal of Personality and Social Psychology, 42(2), 314-321.

Smith, T.W., Snyder, C.R., \& Perkins, S.C. (1983). The self-serving function of hypochondriacal complaints: Physical symptoms as self-handicapping strategies. Journal of Personality and Social Psychology, 44(4), 787-797.

Snyder, C.R., \& Higgins, R.L. (1988). From making to being the excuse: An analysis of deception and verbal/nonverbal issues. Journal of Nonverbal Behavior, 12(4), 237-252.

Snyder, C.R., Smith, T.W., Augelli, R.W., \& Ingram, R.E. (1985). On the self-serving function of social anxiety: Shyness as a self-handicapping strategy. Journal of Personality and Social Psychology, 48(4), 970-980.

Strube, M.J. (1986). An analysis of the Self-Handicapping Scale. Basic and Applied Social Psychology, 7(3), 211-224.

Strube, M.J., \& Roemmele, L.A. (1985). Self-enhancement, self-assessment, and selfevaluative task choice. Journal of Personality and Social Psychology, 49(4), 981-993. 
Thompson, T., \& Richardson, A. (2001). Self-handicapping status, claimed self-handicaps and reduced practice effort following success and failure feedback. The British Journal of Educational Psychology, 71(1), 151-170.

Tice, D.M. (1991). Esteem protection or enhancement? Self-handicapping motives and attributions differ by trait self-esteem. Journal of Personality and Social Psychology, 60(5), 711-725.

Tice, D.M., \& Baumeister, R.F. (1990). Self-esteem, self-handicapping, and self-presentation: The strategy of inadequate practice. Journal of Personality, 58, 443-464. 